\section{THE TEACHING OF SCIENCE}

A

$T$ the Conference on Science and the War Effort A arranged in London recently by the Association of Scientific Workers, there were two sessions devoted to the university training of scientific workers and the training of technical personnel. These sessions, which were attended by well over a hundred people, were remarkable for the wide range of teaching activity represented among both speakers and audience. Nearly every sphere of science teaching was represented, and the speeches dealt with ordinary university and polytechnic courses, the training of State bursars, the part-time teaching of young people in factories and workshops and the special training of recruits and cadets for the Forces. The limitation of time made it impossible to discuss at any length the teaching of science in secondary schools, but it was realized that the problem of scientific education must be tackled as a whole and that the school part of this is of fundamental importance.

Many of the questions discussed were not new, but the present war situation has brought all the old questions sharply to the fore along with some new problems. At the opening of the session on technical education, Mr. E. G. Savage, education officer to the L.C.C., who presided, said that the importance of technical education and the training of technical personnel needs no emphasis at this moment. As we are already bitterly aware, we are engaged in a war in which the quantity and quality of technical personnel is of the highest possible importance. Had we been better prepared in this matter at the outset of the War, it is possible that in at least one field of operations there might have been a different story to tell. As it is, we have been busily engaged in making up very substantial leeway. It is, however, equally important and very relevant to point out that the necessity for trained technical personnel will not diminish when peace comes. Mr. J. M. Keynes was recently quoted as saying that there is no necessity for us to be poorer for very long after the War. Given a proper use of the material resources of the earth and of the skill of our people, we should look forward to an even higher standard of living after the War than before it. To realize this happy issue, however, it is obvious that we shall need much more widespread and much more efficiently trained scientific and technical personnel in our industries and elsewhere.

Mr. J. A. Lauwerys, of the Institute of Education, University of London, said that we lack technically trained people because our secondary education, based on the study of language and literature, is out of touch with the requirements of an industrial society. The traditions which we inherited from ancient slave societies still dominate many of those in charge of our education. They still believe that the studies of highest educative value are those which have nothing to do with the production of useful commodities, and we are suffering from the widespread acceptance of the wrong view that 'culture' and 'vocation' should be kept separate. The question of elementary technical education involves several problems, but the core of the education we need must be scientific studies and not purely literary ones. That is not to say that we should support the proposals of the reactionary and outdated Spens Report with its deplorable suggestions that there should be grammar schools for future administrators, business men, etc., and technical high-schools for future skilled workers. To accept this would be to deepen the existing cleavage, the evil resul $s$ of which have been and still are plain to everybody.

Dr. E. A. Rudge, of the West Ham Municipal College, said that the present difficulties in the supply of scientifically and technically trained people can only be met by the reorganization of schemes of education. This branch of teaching has been neglected over the past twenty years, and the salvaging of technical education should be regarded as a major part of the war effort. The necessary reorganization should be on a national basis, and the scope of local government control should be strictly limited. The raising of the school leaving age is necessary, and this would involve the abolition of fees for full-time students proceeding to technical vocational training. The scientific and teaching professions should recog. nize the inadequacy of present makeshift methods of selection and training, and must plan long-term and carefully organized schemes of education. He urged that we should strive for the setting up of a national advisory committee, including representatives of the scientific and teaching professions, of industry and of the Board of Education.

The important question of part-time training was discussed, and it was generally felt that the scope of this should be much extend d. But this part-time education must be closely linked to the actual work being done in the factory or workshop, because most young people learn better when they feel that the subject is important and see its relevance. Although the better employers have for a long time allowed boys to attend part-time courses during working hours this practice is by no means universal. The Essential Works Order requires firms to provide facilities for technical training, and if this were interpreted to include attendance at technical classes, inside or outside the factory, during working hours, there would be a considerable gain in technical efficiency. It would be desirable to start a sort of tutorial system whereby specially selected men co-operate with the educational authorities in the training of young people.

In this connexion the very important question of vocational guidance was raised. It was felt to be very desirable that there should be a great extension and systematic use of vocational guidance aimed at leading pupils fitted by capacity and inclination into well-designed courses of industrial training. The provision of such guidance on a large scale is a big problem, and it involves other problems such as how to make employers rely on the scheme and how to make it easier for young people who are misfits to change their jobs.

In the discussion on part-time training an important point in connexion with university and hospital laboratories was raised by Mr. B. E. Gilbey. The technical workers in pathological and bacteriological laboratories have developed, largely by their own efforts, into highly trained technologists. Their training extends over five years and is extremely haphazard, depending largely on the good-will of the senior members of the staff, so that they have to have recourse to evening classes which are often unsuitable. The unorganized training and the lack of professional recognition is resulting in the loss to an important profession of a large number of potential technologists at a time when they are urgently needed. 
The inadequacy of the scheme of scientific education in the schools of Great Britain has been strongly underlined by the difficulties facing those who have to train technical personnel in the Services, and these difficulties were discussed at the sessions. There is a shortage of scientific knowledge throughout every grade: there are too few people with degrees, too few with higher school certificate science, too few with matriculation science and too many with no scientific background at all. Scientific weapons and devices have been perfected far more rapidly than people have been trained to use them, and so the limit of efficiency and success is in many cases set by personnel and not by technical advance. Although much has been done recently in many secondary schools, most private schools give little education in science, and the percentage of girls in the Auxiliary Forces with scientific knowledge is very small.

The present situation has vindicated completely those who have fought for the lengthening of the school period and for more science teaching. The need to-day is not only for a wider knowledge of the laws of physics and chemistry, but also for a more scientific attitude to all problems. To take only a few instances, there is a need for the Forces to have more understanding of the usefulness of controlled experiments, of statistical analysis of results, and of scientific tests for the selection of personnel. In some directions the work is good, and this is particularly so where civilian scientific sections responsible for the initial inventions have been asked to help in training. Members of these have the special task of following the new apparatus into operational use, and they have both advised on and taken an active part in the instruction of suitable personnel. In many cases, however, the training covers too narrow a field and is carried out without any regard for educational principles. There are many cases of people being taught to perform some process without being given any idea of where it fits in or even of why they are doing it.

It is quite clear that there is a great need for more technical officers in the Forces who have some training in educational methods, and for people with such training to join the civilian sections. On the other hand, it is vitally necessary that the military authorities should make the fullest use of those members of the Forces who have been trained in technical subjects or in educational methods. In the selection of personnel some sections make good use of psychological tests, but in others deportment, type of school, accent and pure chance still play a large part. This is to be deplored, though in this sphere, as in so many others, the continued efforts of those who are alive to the situation have produced good effects; but much remains to be done.

The session on the university training of scientific workers was presided over by Dr. W. A. Wooster, of the University of Cambridge, and the opening address was by Prof. J. A. Carroll, of the University of Aberdeen. Prof. Carroll stressed the need in modern civilization for a much wider scientific education in addition to the training of the specialist. University science teaching must abandon its present relative isolation and relate itself to its sources, the schools, and to its ends, the production of future teachers, of research workers and of people with a general education. The majority of students do not become research workers, so for the majority the courses are too detailed and too long. We need three types of university science courses: general honours courses for those who are going to teach in schools; special research and technical courses; and general cultural courses for those who intend neither to teach nor to do research.

As regards the supply of young people for university science courses, it is clear that the conditions of entry into British universities require modification. The development of junior, secondary and technical schools might prove very dangerous, because it might easily happen that pupils from these would be cut off from universities under the present conditions of entry. Prof. Carroll stressed the point that the reform of the educational system of Great Britain is long overdue, and that we are paying dearly to-day for the lack of common appreciation of the part which science could play in improving the conditions of life of the community. He also urged the setting up of an advisory committee on scientific education to advise the Board of Education.

The special effects of the war on the problems facing university science teachers were dealt with $\mathrm{Mr}$. R. T. Lattey, acting director of the Electrical Laboratory, Oxford. He spoke of the present teaching of physics there, where four types of students have to be considered-more or less normal undergraduates, State radio bursars, Royal Corps of Signals cadets, and R.A.F. cadets. The most difficult part of the work is to instil a scientific outlook into immature minds, as most of the students have the idea that learning by rote is the end of all knowledge. The bursars come from all types of schools and the qualifications for bursarship as drafted are well below scholarship standard. The scheme can, therefore, be looked on as an interesting experiment of sending to a university pupils who would not get a scholarship in normal times. These students have turned out to be better than might have been expected, and it is clear that the average student has a considerable latent scientific interest and capacity.

Dr. V. E. Cosslett, of the University of Oxford, urged that as an immediate measure there should be proper organization and allocation of available laboratories and the depleted numbers of teaching staff. Very little has been done in the grouping of teachers and courses. Such steps are urgently demanded, for example, in the case of evacuated colleges, and it is certainly true to say that the best possible use is not being made of the limited number of teachers remaining in the universities and colleges.

The sessions on scientific and technical education were very successful in opening up the whole question, and in providing a broad view of the numerous problems involved. Among the speakers and those who took part in the discussion there was unanimous agreement on all the principal issues. The Association of Scientific Workers has begun to form a committee charged with the task of co-ordinating the experience and efforts of all those who are attempting to increase the quantity and improve the quality of scientifically and technically trained people in Great Britain. This is an effort which must succeed if we are to win the War with a minimum of loss, and if we are not to fall hopelessly behind certain other nations in the period of rebuilding after it.

We welcome the decision of the Association to form this committee and hope that it will develop a broad and comprehensive point of view, thus dealing effectively with science teaching in all educational institutions, for faulty education can obviously pass from teacher to taught, or from university to school, and vice versa. 